\title{
Effect of Seed Treatment on Germination in Sarpagandha (Rauvolfia serpentina Benth)
}

\author{
Rahul S. Phatak* , N.K. Hegde, P.M. Gangadharappa and Laxminarayan Hegde \\ KRC College of Horticulture, Arabhavi - 591 218, Karnataka, India \\ *Corresponding author
}

A B S T R A C T

\begin{tabular}{|l|}
\hline Ke y w or d s \\
Seed treatment, \\
Germination, \\
Experiment. \\
\hline Article Info \\
\hline $\begin{array}{l}\text { Accepted: } \\
\text { 04 October } 2017 \\
\text { Available Online: } \\
\text { 10 December } 2017\end{array}$
\end{tabular}

An experiment was carried out to know the effect of different seed treatments on seed germination in sarpagandha. The experiment was laid out in completely randomized design with seven treatments, replicated thrice. Among the different seed treatments tested, $\mathrm{GA}_{3}\left(1000 \mathrm{mg} \mathrm{L}^{-1}\right)$ treatment was found to be the best, recording earliness in first and complete germination, highest values for speed of germination (1.37) and germination percentage $(50 \%)$. The $\mathrm{GA}_{3}$ treatment resulted in 46.94 per cent reduction in number of days to complete germination, 633.93 per cent increased speed of germination and 354.55 per cent increased germination percentage over the control.

\section{Introduction}

Sarpagandha (Rauvolfia serpentina Benth.) is an indigenous medicinal herb of Indian continent, mentioned in ancient Indian medicinal literature, 3000 years back. Sarpagandha is having different vernacular names viz., Sarpagandha in Sanskrit, Chandrabhaga, Chandrika and Chota-Chand in Hindi, Shivanabhi balli, Sarpagandhi, Garuda paatala and Paatala gandhi in Kannada and Serpentine root, Serpentine wood and Indian snake root in English (Anon., 1956). It is used in Ayurveda, Unani, Homeopathy and Sidha systems of medicines for the treatment of high blood pressure, insomnia, cardiac diseases and a number of mental problems such as psychic disorders, mental retardation, epilepsy, agitation and neurotic disorders, asthma, hypochondriasis, certain forms of insanity, acute stomachache and painful delivery. Juice of leaves is used as a remedy for removal of opacities of cornea. Apart from traditional use, it has been increasingly used in pharmaceutical industries.

About 30 alkaloids are known to exist in this plant. The important alkaloids are reserpine, serpentine, ajmaline, ajmalicin, rauvolfinine, recinamine and deserpidine. Rauvolfia serpentina continues to be an important component of traditional medicine within India, as well as the starting material for production of reserpine, with increasing demand. 
Indiscriminate harvesting, loss of habitat, biointerference, over-exploitation, etc. pose serious threat to its wild resources. It has been categorized as an endangered species based on the IUCN (International Union for Conservation of Nature and natural resources) Red Data Book and critically endangered in CAMP, 2001 report (Bhattarai et al., 2002). Sarpagandha is banned for export except when accompanied by certificate of its cultivation. It has become necessary to develop proper agro-technology for its domestication and cultivation on scientific lines. The seed propagated crop is known to give good quality material and higher yield but, seed germination is very poor in sarpagandha. It is reported to vary from 5 to 30 per cent even when only heavy seeds (only about $10 \%$ of normal seed lot) are chosen for sowing.

Germination of heavy seeds during May-June after soaking in water for 24 hours was 20-40 per cent. Though the seeds appear to be perfectly normal externally, the seeds exhibit very poor germination (Farooqui and Sreeramu, 2001). Hence, it is necessary to improve the seed germination, which will be of immense help for commercial cultivation of sarpagandha. With this background, the present experiment was carried out with an objective to enhance the seed germination.

\section{Materials and Methods}

The experiment was conducted at KRC College of Horticulture, Arabhavi, Gokak (Tq.) Belagavi (Dist.), Karnataka during October - December, 2015, to test the effect of different seed treatments on germination in sarpagandha. The seeds were collected from the wild stand of sarpagandha plants found in the evergreen forests of Sirsi, Uttara Kannada (Dist.), Karnataka. The fruits collected from scattered plants found in the lower storey of evergreen forests were pulped manually to extract the seeds. Extracted seeds were washed in clean water and dried in shade. These seeds were subjected to floating test by immersing in water. The seeds which sink in water were selected for germination test. Freshly collected heavy seeds, which sink in water, were used for sowing within a week time.

The experiment comprised of seven treatments with three replications, laid out in Completely Randomized Design. The seeds were subjected to different treatments, $\mathrm{T}_{1}$ : overnight water soaking, $\mathrm{T}_{2}$ : overnight soaking of seeds in $\mathrm{GA}_{3}\left(1000 \mathrm{mg} \mathrm{l}^{-1}\right)$ solution, $\mathrm{T}_{3}$ : soaking seeds in concentrated $\mathrm{H}_{2} \mathrm{SO}_{4}$ for one minute, $\mathrm{T}_{4}$ : overnight soaking of seeds in $\mathrm{KNO}_{3}(1 \%)+\mathrm{HNO}_{3}(1 \%)$ solution, $\mathrm{T}_{5}$ : overnight soaking in cow urine (collected on the previous day), $\mathrm{T}_{6}$ : overnight soaking of seeds in cow dung slurry (cow dung : water in 1:1 ratio) and $T_{7}$ being the control (without any treatment). Hundred seeds were used for soaking in each of the treatments. The seeds after treatment were sown in protrays (of 50 wells), filled with coco peat and watered frequently based on necessity. The protrays were maintained in the indoor (ambient) condition in the laboratory.

\section{Results and Discussion}

\section{Days to first germination}

There was a significant difference among the treatments for days to first germination (Table 1). The minimum number of days taken to first germination was recorded in $\mathrm{GA}_{3}$ (1000 $\mathrm{mg} \mathrm{l}^{-1}$ ) treatment (23). However, it was on par with $\mathrm{H}_{2} \mathrm{SO}_{4}$ (24.33) and cow dung slurry (26). The maximum number of days taken to first germination was recorded in control (37.67). Seed treatment with $\mathrm{GA}_{3}$ treatment resulted in 38.94 per cent reduction in number of days take to first germination over control 


\section{Days to complete germination}

Days from first germination to last germination were counted to get the days to complete germination. There was a significant difference among treatments for this parameter (Table 1). Significantly lower days to complete germination was observed in seeds treated with $\mathrm{GA}_{3}$ (34.67) compared to rest of the treatments. The highest days to complete germination was in cow urine treatment (67.67). Comparison of means for per cent deviation revealed that, the $\mathrm{GA}_{3}$ treatment lead to 46.94 per cent reduction in number of days to complete germination compared to control.

\section{Speed of germination}

As the high speed of germination is indication of high seed vigour, it was recorded to know the effect of seed treatments on the same. The treatments were found to differ significantly for the observed character (Table 1).

The speed of germination was significantly maximum in $\mathrm{GA}_{3}$ treatment (1.37), followed by cow dung slurry $(0.81)$ and $\mathrm{KNO}_{3}+\mathrm{HNO}_{3}$ treatment $(0.67)$. The speed of germination was significantly lower in control (0.19). The seed treatment with $\mathrm{GA}_{3}$ increased the speed of germination by 633.93 per cent compared to control.

\section{Germination percentage}

The germinated seeds were counted and the converted into percentage. The data obtained was subjected to arc sin transformation before analysis. There was a significant difference among the treatments for germination percentage (Table 1). The significantly highest germination was recorded by $\mathrm{GA}_{3}$ treatment $(50.00 \%)$ compared to other treatments, followed by cow dung slurry and $\mathrm{KNO}_{3}+\mathrm{HNO}_{3}$ treatment (36.00 and $29.33 \%$, respectively). The germination was minimum $(11.00 \%)$ in control. When the means of treatments were compared for per cent deviation in germination, seed treatment with $\mathrm{GA}_{3}$ recorded 354.55 per cent increase over control.

Seed treatments have shown the variable influence on days to first germination, days to complete germination, speed of germination and germination percentage. All the seed treatments proved the early germination over control and there was a significant difference among the treatments for days to first germination.

The minimum number of days taken to first germination was in $\mathrm{GA}_{3}\left(1000 \mathrm{mg} \mathrm{l}^{-1}\right)$ treatment (23 days) which was however, on par with $\mathrm{H}_{2} \mathrm{SO}_{4}$ (24.33 days), and $\mathrm{KNO}_{3}+$ $\mathrm{HNO}_{3}$ treatment (27 days). The delayed germination was in the control (37.67 days). Comparison of treatments means revealed that, the seeds treated with $\mathrm{GA}_{3}$ took 38.94 per cent lower days to first germination, when compared to control. The earlier germination in $\mathrm{GA}_{3}$ treatment might be attributed to the conversion of reserve food material into available simple sugar form by early induction of protein, $\alpha$ - amylase, in aleurone layer by forming m-RNA for protein ( $\alpha$ amylase) synthesis and inhibitory action of exogenously applied gibberellins on IBA present in seeds, leading to early germination (Bewley and Black, 1994).

Acid scarification increased the seed germination by improving seed permeability and removing the blockage of gaseous exchange, which might have improved the imbibition and respiration. This early availability of water and oxygen might have induced the early germination. Similar results have been reported by Ponkumar et al., (2008) in sarpagandha, Bhuse et al., (2001) and Moorthy et al., (2005) in senna. 
Table.1 Seed germination as influenced by seed treatment in sarpagandha

\begin{tabular}{|c|c|c|c|c|c|c|c|c|}
\hline \multirow{2}{*}{ Treatment } & \multicolumn{2}{|c|}{ Days to first germination } & \multicolumn{2}{|c|}{$\begin{array}{l}\text { Days to complete } \\
\text { germination }\end{array}$} & \multicolumn{2}{|c|}{ Speed of Germination } & \multicolumn{2}{|c|}{ Germination (\%) } \\
\hline & mean & $\begin{array}{c}\text { Per cent } \\
\text { deviation* }\end{array}$ & mean & $\begin{array}{c}\text { Per cent } \\
\text { deviation* }\end{array}$ & mean & $\begin{array}{c}\text { Per cent } \\
\text { deviation* }\end{array}$ & mean & $\begin{array}{c}\text { Per cent } \\
\text { deviation* }\end{array}$ \\
\hline $\mathrm{T}_{1}$ : Water soaking & 35.33 & -6.19 & 60.33 & -7.65 & 0.32 & +69.64 & $\begin{array}{c}16.67 \\
(23.85)\end{array}$ & +51.52 \\
\hline $\mathrm{T}_{2}: \mathrm{GA}_{3}\left(1000 \mathrm{mg} \mathrm{l}^{-1}\right)$ & 23.00 & -38.94 & 34.67 & -46.94 & 1.37 & +633.93 & $\begin{array}{c}50.00 \\
(45.00)\end{array}$ & +354.55 \\
\hline $\mathrm{T}_{3}$ : Conc. $\mathrm{H}_{2} \mathrm{SO}_{4}$ (for $1 \mathrm{~min}$.) & 24.33 & -35.40 & 54.00 & -17.35 & 0.47 & +150.00 & $\begin{array}{c}20.00 \\
(26.45)\end{array}$ & +81.82 \\
\hline $\mathrm{T}_{4}: \mathrm{KNO}_{3}+\mathrm{HNO}_{3}(1 \%$ each $)$ & 27.00 & -28.32 & 55.33 & -15.31 & 0.67 & +258.93 & $\begin{array}{c}29.33 \\
(32.72)\end{array}$ & +166.67 \\
\hline $\mathrm{T}_{5}$ : Cow urine treatment & 31.33 & -16.81 & 67.67 & +3.57 & 0.32 & +69.64 & $\begin{array}{c}17.00 \\
(24.29)\end{array}$ & +54.55 \\
\hline $\mathrm{T}_{6}$ : Cow dung treatment & 26.00 & -30.97 & 58.00 & -11.22 & 0.81 & +332.14 & $\begin{array}{c}36.00 \\
(36.85)\end{array}$ & +227.27 \\
\hline $\mathrm{T}_{7}$ : Control & 37.67 & - & 65.33 & - & 0.19 & - & $\begin{array}{c}11.00 \\
(19.19)\end{array}$ & - \\
\hline S.Em \pm & 0.83 & - & 1.66 & - & 0.02 & - & 0.71 & - \\
\hline C.D. at $1 \%$ & 3.48 & - & 6.98 & - & 0.07 & - & 3.00 & - \\
\hline $\mathrm{CV}(\%)$ & 4.89 & - & 5.08 & - & 4.99 & - & 4.80 & - \\
\hline
\end{tabular}

*Per cent deviation for the pooled mean of respective treatment over control 
The speed of germination was significantly higher in $\mathrm{GA}_{3}$ treatment (1.37) followed by cow dung slurry (0.81) and $\mathrm{KNO}_{3}+\mathrm{HNO}_{3}$ treatment (0.67) whereas, the lowest was observed in control (0.19). The seed treatment with $\mathrm{GA}_{3}$ increased the speed of germination by 633.93 per cent compared to control. Improved speed of germination in $\mathrm{GA}_{3}$ may be due to increased GA: ABA ratio in the seeds by exogenous application of $\mathrm{GA}_{3}$ which could have overcome the inhibitory effect of ABA present in seeds and inhibition of mRNA synthesis which might have been accelerated by gibberellins (Bewley and Black, 1994).

There was a differential response among seed treatments for days to complete germination. The treatments were differing significantly and induced early completion of germination. The data revealed that, days to complete germination was minimum in $\mathrm{GA}_{3}$ treatment (34.67), followed by $\mathrm{H}_{2} \mathrm{SO}_{4}$ treatment (54 days) compared to control (65.33 days). The $\mathrm{GA}_{3}$ treatment led to 46.94 per cent reduction in number of days to complete germination over control. The early completion of germination may be attributed to enhanced early germination in $\mathrm{GA}_{3}$ treatment due to quicker imbibitions and mobilization of reserve food in seed.

With respect to germination percentage, the maximum germination was in $\mathrm{GA}_{3}$ treatment $(50 \%)$ which was significantly higher than rest of the treatments. The lowest germination was observed in control $(11 \%)$. Seed treatment with $\mathrm{GA}_{3}$ recorded 354.55 per cent more germination over control. The highest percentage of germination observed in $\mathrm{GA}_{3}$ might be due to efficient utilization of limited food reserve present in the seeds by early induction of $\alpha$ - amylase activity. Similar results have been reported by Bhuyar et al., (2000) and Ponkumar et al., (2008) in Rauvolfia serpentina, Bhuse et al., (2001) in senna, Mithra and Ghosh (2004) in aswagandha. Whereas, Paul, et al., (2008) reported that, none of the chemical or acid seed treatments improved germination percentage significantly in sarpagandha. The germination percentages of treated Rauvolfia tetraphylla seeds were improved to 52.70 per cent $\left(\mathrm{KNO}_{3}\right)$ and 56.66 per cent $\left(\mathrm{GA}_{3}\right)$ as compared to 31.26 per cent in untreated seeds (Hussain and Jha, 2014).

Among the different seed treatments tested in sarpagandha, $\mathrm{GA}_{3}\left(1000 \mathrm{mg} \mathrm{\textrm {L } ^ { - 1 }}\right)$ treatment was found to be the best, recording early germination, highest values for speed of germination, germination percentage, shoot and root length and vigour index. The $\mathrm{GA}_{3}$ treatment resulted in 46.94 per cent reduction in number of days to complete germination, 633.93 per cent increased speed of germination, and 354.55 per cent increased germination percentage over the control.

\section{References}

Anonymous, 1956. The Wealth of India- Raw Materials. Council of Scientific and Industrial Research, New Delhi, 4: 139140.

Bewley, J. D. and Black, M., 1994. Control of the mobilization of stored reserves, seeds physiology of development and germination. Plenum Press, New York, Pp. 346- 351.

Bhattarai, N. K., Tandon, V. and Ved, D. K., 2002. Highlights and outcomes of the conservation assessment and management plan (CAMP) workshop. In: Proceedings, Regional Workshop on Sharing Local and National Experience in Conservation of Medicinal and Aromatic Plants in South Asia, 21-23 January 2001, Pokhara, Nepal, pp 4653.

Bhuse, V. H., Lad, B. L. and Ghule, S. T., 2001. Effect of various seed treatments 
for enhancement of seed germination and seedling vigour in senna (Cassia angustifolia). Res. Crops 2 (3): 359363.

Bhuyar, S. A., Wankhade, S. G., Paturde, J. T. and Khode, P. P., 2000. Seed germination studies in sarpagandha (Rauvolfia serpentina Benth). Res. Crops, 1 (2): 189-191.

Farooqi, A. A. and Sreeramu, B. S., 2001. Cultivation of medicinal and aromatic crops. Universities press (India) Limited, pp234-241.

Hussain, A. and Jha, D. K., 2014. Seed germination improvement in two threatened medicinal plants. Curr. Agric. Res. J., 2(2): 131-136.
Mithra, M. and Ghosh, P., 2004, Effect of chemicals and soaking duration on seed germination of aswagandha (Withania somnifera). J. Interacademicia 8(2): 302-304.

Moorthy, K. R., Rajendran, C. and Sivasubramanian, S., 2005. Seed treatment for alleviation of hard seededness in senna (Cassia angustifolia L.) Adv. Pl. Sci. 18(1): 429430.

Ponkumar, P., Padma, M., Rajkumar, M. and Madulety, T. Y., 2008. Effect of chemicals and plant growth substances on breaking of seed dormancy in sarpagandha (Rauvolfia serpentina L.). J. Res. ANGRAU, 36(1): 54-56.

\section{How to cite this article:}

Rahul S. Phatak, N.K. Hegde, P.M. Gangadharappa and Laxminarayan Hegde. 2017. Effect of Seed Treatment on Germination in Sarpagandha (Rauvolfia serpentina Benth). Int.J.Curr.Microbiol.App.Sci. 6(12): 135-140. doi: https://doi.org/10.20546/ijcmas.2017.612.018 